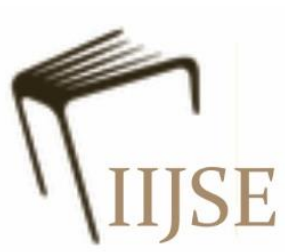

\title{
PENGARUH EFISIENSI, KUALITAS AKTIVA, LIKUIDITAS, SENSITIVITAS DAN SOLVABILITAS TERHADAP ROA PADA BANK SWASTA NASIONAL NON DEVISA
}

\author{
Lutvi Alamsyah ${ }^{1}$ \\ Institut Pesantren KH. Abdul Chalim \\ lutvi@ikhac.ac.id
}

\begin{abstract}
Abstrak
Kata kunci:

Efisiensi, Aktiva,

Likuiditas,

Sensivitas,

Solvabilitas,

Profitabilitas

Penelitian ini bertujuan untuk menganalisis apakah LDR, APB, NPL, BOPO, AUR, PPAP, PR, IPR dan IRR memiliki pengaruh signifikan terhadap ROA pada Bank Umum Swasta Nasional. Sampel penelitian ini yaitu: PT. Bank Harda Internasional, PT. Bank Jasa Jakarta, PT. Bank Kesejahteraan Ekonomi, PT. Bank Pundi Indonesia, PT. Bank Tabungan Pensiunan Nasional, PT. Bank Yudha Bhakti dan metode pengumpulan data dalam penelitian ini adalah purposive sampling dengan data sekunder periode 2008 sampai 2010. Teknik analisis data menggunakan analisis regresi. Hasil penelitian menunjukkan bahwa LDR, memiliki pengaruh yang signifikan terhadap ROA, BOPO berpengaruh negatif signifikan terhadap ROA. AUR, PR dan IPR berpengaruh tidak signifikan terhadap ROA. IRR, APB, NPL, dan PPAP memiliki pengaruh negatif tidak signifikan terhadap ROA pada Bank Umum Swasta Nasional Non-Bank Devisa.
\end{abstract}

\section{Abstract}

Keyword:

Efficiency,

Assets, Liquidity,

Sensitivity,

Solvability,

Profitability
This study aims to analyze whether the LDR, APB, NPL, BOPO, AUR, PPAP, PR, IPR and IRR have a significant influence on ROA on the National Private Commercial Bank. The research sample are: PT. Bank Harda Internasional, PT. Bank Jasa Jakarta, PT. Bank Kesejahteraan Ekonomi, PT. Bank Pundi Indonesia, PT. Bank Tabungan Pensiunan Nasional, PT. Bank Yudha Bhakti and the data collection method in this study was purposive sampling with secondary data from 2008 to 2010 . The data analysis technique uses regression analysis. The results showed that the LDR had a significant effect on ROA, BOPO had a significant negative effect on ROA. AUR, PR and IPR have no significant effect on ROA. IRR, APB, NPL, and PPAP have no significant negative effect on ROA on the National Private Commercial Bank. 


\section{A. Pendahuluan}

Bank merupakan lembaga keuangan yang kegiatan utamannya sebagai lembaga intermediasi yang tugasnya menghimpun dana dari masyarakat yang kekurangan dana dalam bentuk kredit atau pemberian pinjaman serta memberikan jasa bank lainnya. Dalam satu usaha yang ingin diperoleh adalah keuntungan atau laba begitu pula yang ingin diperoleh bank, sehingga dalam kegiatan operasional sehari-hari salah satu tujuan bank adalah memperoleh keuntungan yang dapat diukur dengan rasio keuangan yang salah satu diantaranya adalah rasio Return On Asset (ROA).

Tinggi rendahnya ROA yang dimiliki oleh bank akan sangat tergantung pada kebijakan atau strategi yang digunakan oleh manajemen bank yang terkait dengan Aspek Efesiansi Kualitas Aktiva Likuiditas, Sensitivitas, Solvabilitas terhadap Return on Asset (ROA). Rasio Likuiditas digunakan untuk mengukur kemampuan bank dalam memenuhi kewajiban-kewajiban jangka pendek atau membayar kembali simpanan atau uang nasabah pada saat penarikan. Jika bank lalai dalam mengelola likuiditasnya maka akan berakibat buruk pada citra bank yang bersangkutan dan kepercayaan masyarakat pada bank tersebut.
Rasio efisiensi digunakan untuk mengukur kinerja manajemen suatu bank apakah telah menggunakan faktor produksinya dengan tepat dan hasil guna, maka dengan rasio keuangan kita dapat mengukur secara kualitatif tingkat efisiensi yang dicapai manajemen bank (Martono 2007). Untuk mengukur tingkat efisiensi dan kinerja bank dapat menggunakan rasio BOPO (Beban operasional terhadap Pendapatan operasional) dan AU (Asset Utilization).

Sensitivitas adalah penilaian terhadap kemampuan modal bank untuk mengcover akibat yang ditimbulkan oleh perubahan risiko pasar dan kecukupan manajemen risiko pasar (Veithzal Rivai, dkk 2007). Kemampuan bank dalam menanggapi keadaan pasar sangat berpengaruh pada tingkat profitabilitas suatu bank. Sensitivitas terhadap pasar dapat diukur dengan menggunakan rasio IRR (Interest Risk Ratio) dan PDN (Posisi Devisa Neto).

Solvabilitas adalah kemampuan bank dalam memenuhi kewajiban jangka panjangnya atau kemampuan bank untuk memenuhi kewajiban jika terjadi likuidasi bank (Dendawijaya, 2009). Solvabilitas yang dimiliki juga memiliki peran sangat penting dalam menunjang kegiatan operasional bank seharihari. Dalam perkembangan operasi suatu bank, modal dapat berkurang diakibatkan dari adanya kerugian atau kegagalan usaha, 
sedangkan pertambahan modal dapat berasal dari keuntungan usaha lain, seperti pendapatan dari fee based income untuk jasa perbankan yang diberikan pada masyarakat.

Menurut penjelasan tersebut dapat diambil kesimpulan bahwa upaya dalam mendapatkan ROA sesuai dengan yang diinginkan manajemen bank perlu mengetahui faktorfaktor yang bisa mempengaruhi tinggi rendahnya ROA. Demikian halnya yang dilakukan oleh bank swasta non devisa yang berpusat di Surabaya sehingga dapat maksimalkan keuntungan.

\section{B. Kajian Pustaka}

1. Kinerja Keuangan Bank

Kinerja keuangan bank merupakan bagian dari kinerja bank secara keseluruhan (performance) dan merupakan gambaran prestasi yang dicapai bank dalam keseluruhan kegiatan operasionalnya, baik menyangkut aspek Likuiditas, aspek Kualitas Aktiva, aspek Efisiensi, aspek Solvabilitas dan aspek Sensitivitas (SEBI No.6/23/DPNP Tanggal 31 April 2004). Kinerja bank juga merupakan pedoman hal-hal apa saja yang perlu diperbaiki dan bagaimana cara atau solusi yang tepat untuk memperbaikinya.

Penilaian tingkat kesehatan bank menurut SEBI No.6/23/DPNP Tanggal 31 April 2004 mencakup penilaian terhadap faktor-faktor CAMELS yang terdiri dari: a) Permodalan
(Capital), b) Kualitas Aset (Asset Quality), c) Manajemen, d) Rentabilitas (earning), e) Likuiditas (Liquidity), f) Sensitivitas terhadap risiko pasar (Sensitivity to Market Risk).

2. Rasio Likuiditas

Menurut Lukman Dendawijaya ( 2009:114 ) yang dimaksud dengan likuiditas bank adalah kemampuan bank dalam memenuhi kewajiban- kewajiban jangka pendeknya atau kewajiban yang sudah jatuh tempo. Secara lebih spesifik, likuiditas adalah kesanggupan bank menyediakan aktiva yang likuid agar dapat membayar kembali titipan yang sudah jatuh tempo dan memberikan pinjaman (Loan) kepada masyarakat yang memerlukan.

Menurut Lukman Dendawijaya (2009:114117) pengukuran likuiditas bank dapat diukur dengan rasio-rasio sebagai berikut: a) Investing Policy Ratio (IPR), b) Loan to Deposit Ratio, c) One Month Mismatch Maturity Ratio, d) Proyeksi Cash Flow 3 bulan mendatang, e) Ketergantungan pada dana antar bank dan deposan inti, f) Kebijakan dan Pengelolaan Likuiditas (Asset and Liabilities Management / ALMA), g) Kemampuan Bank untuk memperoleh akses kepada pasar modal, h) Stabilitas Dana Pihak Ketiga.

3. Rasio Kualitas Aktiva Bank

Menurut Veithzal Rivai, dkk (2007:713) penilaian kualitas asset merupakan penilaian terhadap kondisi asset bank dan kecukupan 
manajemen risiko kredit. Untuk menghitung tingkat kualitas aset, kita dapat menggunakan rasio-rasio antara lain: a) Aktiva produktif bermasalah, b) Non-Performing Loan, c) Bad Debt Ratio, d) Debitur inti kredit diluar pihak terkait dibandingkan dengan total kredit, e) Tingkat kecukupan pembentukan PPAP, f) Kecukupan kebijakan dan prosedur Aktiva Produktif, g) Sistem kaji ulang (review) internal terhadap aktiva produktif, h) Dokumentasi aktiva produktif, dan i) Kinerja penanganan Aktiva Produktif Bermasalah

\section{Rasio Solvabilitas}

Aspek permodalan merupakan kemampuan bank dalam memenuhi kewajiban jangka panjangnya atau kemampuan bank untuk memenuhi kewajiban-kewajiban jika terjadi likuidasi bank (Lukman Dendawijaya 2009:120), bisa juga dikatakan sebagai alat ukur untuk melihat efisiensi bagi pihak manajemen bank tersebut. Modal merupakan salah satu faktor penting bagi suatu bank dalam rangka pengembangan kegiatan usaha serta untuk menampung risiko-risiko yang mungkin terjadi.

Rasio-rasio yang digunakan untuk mengukur solvabilitas bank diantaranya: a) Fixed Asset to Capital Ratio (FACR), b) Kemampuan Bank memelihara kebutuhan penambahan modal yang berasal dari keuntungan (laba ditahan), c) Rencana permodalan untuk mendukung pertumbuhan usaha, d) Capital Adequacy Ratio, e) Komposisi permodalan Proyeksi CAR, f) Rasio Aktiva Produktif yang Diklasifikasikan terhadap Modal Bank, g) Akses kepada sumber permodalan, h) Primary ratio, dan i) Kinerja keuangan pemegang saham untuk meningkatkan permodalan bank.

5. Rasio Profitabilitas

Menurut Lukman Dendawijaya (2009:118) yang dimaksud dengan analisis rasio rentabilitas bank adalah alat untuk menganalisis atau mengukur tingkat efisiensi usaha dan profitabilitas yang dicapai oleh bank yang bersangkutan, selain itu, rasio-rasio dalam kategori ini dapat pula digunakan untuk mengukur tingkat kesehatan bank.

Menurut SEBI No. 7/10/DPNP tanggal 31 Maret 2005, rasio-rasio yang digunakan untuk mengukur profitabilitas bank diantaranya: a) Return on Asset (ROA), b) Return on equity (ROE), dan c) Net Interest Margin (NIM)

\section{Rasio Efisiensi Bank}

Rasio efisiensi digunakan untuk mengukur kinerja manajemen suatu bank apakah telah menggunakan faktor produksinya dengan tepat dan hasil guna, maka dengan rasio keuangan kita dapat mengukur secara kualitatif tingkat efisiensi yang dicapai manajemen bank (Martono 2007:86).

Kemudian menurut SEBI No. 6/23/DPNP tanggal 31 Mei 2004. BOPO merupakan rasio 
yang mengukur efisiensi suatu bank dengan menggunakan perbandingan antara beban operasional dengan perolehan pendapatan operasional. Rasio ini dapat dihitung dengan rumus: a) BOPO (Biaya Operasional Pendapatan Operasional), b) Asset Utilization, dan c) Perkembangan laba operasional.

\section{Rasio Sensitivitas}

Sensitivitas merupakan penilaian terhadap kemampuan modal bank untuk mengcover akibat yang ditimbulkan oleh perubahan risiko pasar dan kecukupan manajemen risiko pasar (Veithzal Rivai, dkk 2007 ; 725). Untuk menghitung tingkat sensitivitas terhadap pasar, kita dapat menggunakan rasio-rasio sebagai berikut: a) IRR (Interest Rate Risk), b) Posisi Devisa Neto (PDN), dan c) Rasio modal atau cadangan yang dibentuk untuk mengcover fluktuasi suku bunga dibandingkan dengan Potential Loss Suku Bunga.

\section{Metode Penelitian}

Jenis penelitian ini adalah penelitian kuantitatif dengan pendekatan kausalitas. Dalam penelitian ini peneliti mengambil data dari populasi bank- bank umum swasta non devisa, penentuan sampelnya menggunakan teknik purposive sampling. Yaitu menentukan sampel yang dipilih dengan kreteria yang digunaka penelitian adalah bank-bank umum swasta non devisa yang memiliki total asset di atas 1 Triliun per September 2010. Variabel- variabel yang digunakan dalam penelitian ini meliputi: 1) Loan to Deposit Ratio $\left.\left(\mathrm{X}_{1}\right), 2\right)$ Investing policy rasio $\left.\left(\mathrm{X}_{2}\right), 3\right)$ Aktiva produkti Bermasalah $\left.X_{3}\right)$, 4) NPL $\left(X_{4}\right)$, 5) Asset Utilization $\left.\left(\mathrm{X}_{5}\right), 6\right)$ Penyisihan Penghapusan Aktiva Produktif $\left.\left(\mathrm{X}_{6}\right),{ }^{7}\right)$ BOPO $\left.\left(\mathrm{X}_{7}\right), 8\right)$ Primary Ratio $\left(\mathrm{X}_{8}\right)$, 9) IRR $\left(\mathrm{X}_{9}\right)$, 10) ROA (Y). Untuk menguji hipotesis dilakukan analisis regresi untuk menentukan arah dan besarnya pengaruh variable bebas terhadap variabel tergantung. Persamaan statistic untuk uji tersebut: $Y=\alpha+\beta_{1} X_{1}+\beta_{2} X_{2}+\beta_{3} X_{3}+\beta_{4} X_{4}+$ $\beta_{5} X_{5}+\beta_{6} X_{6}+\beta_{7} X_{7}+\beta_{8} X_{8}+$ ei

\section{Hasil dan Pembahasan}

Analisis regresi linier berganda digunakan untuk mengetahui seberapa besar pengaruh hubungan antara variabel bebas terhadap variable tergantung. Untuk mempermudah dalam menganalisa regresi linier berganda berikut ini akan menyajikan hasil pengolahan data sebagai berikut:

\section{Tabel 1 Hasil Regresi Berganda}

\begin{tabular}{|ll|r|}
\hline \multicolumn{2}{|c|}{ Variabel Penelitian } & Koefisien Regresi \\
\hline LDR & $(\mathrm{X} 1)$ & 0.055 \\
\hline IPR & $(\mathrm{X} 2)$ & 0.039 \\
\hline APB & $(\mathrm{X} 3)$ & -0.096 \\
\hline NPL & $(\mathrm{X} 4)$ & -0.204 \\
\hline AUR & $(\mathrm{X} 5)$ & -0.026 \\
\hline PPAP & $(\mathrm{X} 6)$ & 0.030 \\
\hline BOPO & $(\mathrm{X} 7)$ & 0.001 \\
\hline PR & $(\mathrm{X} 8)$ & -0.016 \\
\hline IRR & $(\mathrm{X} 9)$ & -0.003 \\
\hline R. Square & & 0.636 \\
\hline Sig F & 0.000 \\
\hline Konstanta/constanta & -0.064 \\
\hline \multicolumn{2}{|l|}{ F Hitung } \\
\multicolumn{3}{|l|}{} \\
Sumber: data diolah $(2015)$ & 12.018 \\
\hline
\end{tabular}


Berdasarkan tabel diatas dapat ditarik beberapa kesimpulan sebagai berikut:

1. Apabila variabel Loan to Deposito Ratio dinaikkan 1 persen maka akan terjadi kenaikan ROA sebesar 5,5\%

2. Apabila variabel Investing Policy Ratio dinaikkan $1 \%$ maka akan terjadi penurunan ROA sebesar 3,9\%

3. Apabila variabel Aktiva Produktif Bermasalah dinaikkan 1\% maka akan terjadi penurunan ROA sebesar 9,6\%

4. Apabila variabel Non Performing Loan dinaikkan $1 \%$ maka akan terjadi kenaikan ROA sebesar $20,4 \%$

5. Apabila variabel Asset Utilization dinaikkan $1 \%$ maka akan terjadi penurunan ROA sebesar $2,6 \%$

6. Apabila variabel Penyisihan Penghapusan Aktiva Produktif dinaikkan 1\% maka akan terjadi penurunan ROA sebesar 3,0\%

7. Apabila variabel BOPO dinaikkan $1 \%$ maka terjadi penurunan ROA sebesar $0,1 \%$

8. Apabila variabel Primary Ratio dinaikkan 1 persen maka akan terjadi kenaikan ROA sebesar $1,6 \%$

9. Apabila variabel Interest Rate Risk dinaikkan 1 persen maka akan terjadi penurunan ROA sebesar $0,3 \%$
Tabel 2 Uji t

\begin{tabular}{|l|r|r|l|l|c|}
\hline Variabel & $\mathrm{t}_{\text {hitung }}$ & $\mathrm{t}_{\text {tabel }}$ & \multicolumn{1}{|c|}{$\mathrm{H}_{0}$} & \multicolumn{1}{|c|}{$\mathrm{H}_{1}$} & $\mathrm{r}^{2}$ \\
\hline LDR & 2,844 & 1.6698 & Ditolak & Diterima & 0,1156 \\
\hline IPR & 2,236 & 1.6698 & Ditolak & Ditolak & 0,0801 \\
\hline APB & $-3,662$ & -1.6698 & Ditolak & Diterima & 0,1781 \\
\hline NPL & $-2,795$ & -1.6698 & Ditolak & Diterima & 0,1122 \\
\hline AUR & $-0,126$ & 1.6698 & Diterima & Ditolak & 0,0003 \\
\hline PPAP & 4,381 & -1.6698 & Diterima & Ditolak & 0,2362 \\
\hline BOPO & 1,186 & -1.6698 & Diterima & Ditolak & 0,0222 \\
\hline PR & $-0,821$ & 1.6698 & Diterima & Ditolak & 0,0108 \\
\hline IRR & $-0,279$ & 1.99897 & Diterima & Ditolak & 0,0012 \\
\hline
\end{tabular}

Sumber: data diolah (2015)

Berdasarkan tabel diatas dapat ditarik beberapa kesimpulan sebagai berikut:

1. Variabel LDR mempunyai pengaruh yang signifikan terhadap variabel ROA

2. Variabel IPR mempunyai pengaruh yang signifikan terhadap variabel ROA

3. Variabel APB mempunyai pengaruh yang tidak signifikan terhadap variabel ROA

4. Variabel NPL mempunyai pengaruh yang signifikan terhadap variabel ROA

5. Variabel AU mempunyai pengaruh yang tidak signifikan terhadap variabel ROA

6. Variabel PPAP mempunyai pengaruh yang tidak signifikan terhadap variabel ROA

7. Variabel BOPO mempunyai pengaruh yang tidak signifikan terhadap variabel ROA

8. Variabel PR mempunyai pengaruh yang tidak signifikan terhadap variabel ROA

9. Variabel IRR mempunyai pengaruh yang tidak signifikan terhadap variabel ROA.

Berdasarkan hasil analisis regresi linier berganda, diketahui bahwa:

1. Berdasarkan teori hubungan LDR dengan ROA adalah positif. Hasil analisis regresi 
menunjukkan hasil yang sama. Dimana variabel LDR secara rata-rata mengalami penurunan sebesar $8,4 \%$ yang berarti penurunan jumlah Kredit lebih besar darapada penurunan DPK, yang akan menyebabkan Pendapatan Bunga kredit turun, kemudian Pendapatan Operasional juga trun, Profit turun dan ROA juga mengalami penurunan.

2. Hasil penelitian menunjukkan tidak sesuai dengan teori. Kenaikan jumlah surat-surat berharga mengakibatkan kenaikan pendapatan bunga dari sura-surat berharga tersebut. Namun, pendapatan bunga atas aktiva produktif lainnya (selain surat-surat berharga) mengalami penurunan yang lebih besar daripada kenaikan pendapatan bunga atas surat-surat berharga tersebut, sehingga pendaptan operasional bank mengalami penurunan, dan profit juga turun sehingga ROA juga mngalami penurunan.

3. Hasil uji variabel APB terhadap ROA adalah berlawanan, dan ini harusnya sesuai dengan teori. Variabel APB pada penelitian ini secara rata-rata mengalami kenaikan sebesar 3,4\% yang berarti kenaikan aktiva produktif bermasalah lebih besar daripada kenaikan aktiva produktf. Kenaikan APB mengakibatkan penurunan pendapatan bunga atas aktiva produktif bank, sehingga pendapatan operasional bank juga mengalami penurunan, akibatnya profit juga turun dan ROA juga mengalami penurunanan.

4. Hasil uji variabel NPL terhadap ROA adalah berlawanan arah, dan hal ini harusnya sesuai dengan teori. Pada penelitian ini variabel NPL secara rata-rata mengalami penurunan $0,3 \%$ yang berarti penurunan kredit bermaslah lebih besar daripada penurunan total kredit. Penurunan NPL menunjukan bahwa kualitas kredit mengalami kenaikan sehingga pendapatan bunga kredit juga mengalami kenaikan. Tetapi, pendapatan bunga atas aktiva produktif bank yang lain mengalami penurunan yang lebih besar dari kenaikan pendapatan bunga kredit, sehingga pendapatan operasional bank justru mengalami penurunan. Turunnya pendapatan operasional bank menyebabkan menurunnya profit sehingga ROA juga ikut turun.

5. Hasil uji variabel AU terhadap ROA mempunyai pengaruh berlawanan dan hal ini tdak sesuai dengan teori. Pada penelitian ini variabel AU mengalami kenaikan sebesar 0,5\% yang berarti kenaikan pendapatan operasional dan non operasional lebih besar daripada kenaikan total aset. Namun, kenaikan pendapatan operasional dan non opersional pada penelitian ini masih lebih 
rendah dari kenaikan beban operasional, sehingga profit operasional bank mengalmi penurunan dan ROA juga turun.

6. Hasil uji variabel PPAP terhadap ROA mempunyai koefisien regresi sebesar 0,030 dan hal ini tdak sesuai dengan teori, variabel PPAP secara rata-rata menglami penurunan sebesar 7,2\%, yang brarti penurunan PPAP yang telah dibentuk lebih besar dari PPAP yang wajib dibentuk,. Penurunan PPAP yang telah dibentuk menyebabkan kenaikan jumlah aktiva prodktif, sehingga pendapatan bunga atas aktiva produktif naik dan pendaptan operasional bank naik. Namun, kenaikan beban operasional lebh besar daripada pendapatan operasional, dan hal ini menyebabkan profit turun dan ROA juga turun.

7. Hasil pengujian variabel BOPO mempunyai koefisien regresi sebesar 0,001 dan hal ini tidak sesuai degan landasan teori, variabel BOPO secara rata-rata turun sebesar 1,97\%. Berarti penurunan beban opereasional lebih besar pendapatan operasional sehingga profit naik. Namun, kenaikan total aktiva lebih bsar daripada kenaikan total profit sehingga ROA mengalami penurunan.

8. Hasil uji variabel PR mempunyai koefisien regresi sebesar -0,016 dan hal ini tdak sesuai degan teori, variabel PR secara ratarata mengalami kenaikan sebesar 0,09\%.
Hal ini berarti kenaikan modal lebih besar daripada total aktiva. Kenaikan modal mengakibatkan kenaikan alokasi jumlah aktiva produktif yang kemudian meningkatkan pendapatan bunga atas aktiva produktif. Kenaikan bunga atas aktiva produktif mengakibatkan kenaikan pendapatan operasional bank dan profit naik, akan tetapi kenaikan total aktiva lebih besar daripada kenaikan profit sehingga ROA menurun.

9. Variabel IRR mempunyai koefisien regresi sebesar -0,003 dan hal ini sesuai degan teori, pada penelitian ini rata-rata IRR sebesar $50,88 \%$ dan jika terjadi kenaikan tingkat bunga maka kenaikan tingkat pendapatan bunga lebih kecil dari biaya bunga sehingga ROA turun dan profit juga turun. Hal ini menyatakan bahwa suku bunga mengalami kenaikan yang menyebabkan kenaikan IRSA lebih besar daripada kenaikan IRSL sebesar 12 persen, sehingga menyebabkan kenaikan pendapatan bunga lebih besar daripada kenaikan biaya bunga. Hal ini dikarenakan komponen kredit yang diberikan jumlahnya paling besar diantara komponen IRSA yang lain. Maka pendapatan akan mengalami peningkatan, laba yang pada akhirnya berpengaruh pada peningkatan ROA.

Berdasarkan hasil uji F yang sudah dilakukan ternyata diketahui bahwa terdiri LDR, IPR, 
APB, NPL, AUR, PPAP, BOPO, PR, dan IRR secara simultan (bersama-sama) memiliki pengaruh yang signifikan terhadap ROA.

Koefisien determinasi $\left(\mathrm{R}^{2}\right)$ sebesar 0,636 menunjukkan 63,6\% perubahan ROA Bankbank Swasta Nasional Non Devisa dipengaruhi oleh variabel LDR, IPR, APB, PPAP, NPL, BOPO, AU, IRR, PDN dan PR dan sisanya sebesar $37 \%$ disebabkan oleh faktor lain yang tidak dimasukkan dalam penelitian ini.

\section{E. Penutup}

Berdasarkan analisis data dan pengujian hipotesis dapat ditarik kesimpulan sebagai berikut:

1. Variabel LDR, IPR, APB, NPL, AUR, PPAP, BOPO, PR, dan IRR secara bersama-sama mempunyai pengaruh yang signifikan terhadap ROA pada Bank-bank Swasta Nasional Non Devisa.

2. Variabel LDR, IPR, dan PPAP secara parsial mempunyai pengaruh positif yang signifikan terhadap ROA pada Bank-bank Swasta Nasional Non Devisa.

3. Variabel BOPO secara parsial mempunyai pengaruh positif yang tidak signifikan terhadap ROA pada Bank-bank Swasta Nasional Non Devisa.

4. Variabel APB dan AUF secara parsial mempunyai pengaruh negatif tidak signifikan terhadap ROA.
5. Variabel NPL dan PR secara parsial mempunyai pengaruh negatif tidak signifikan terhadap ROA.

\section{F. Daftar Pustaka}

Bank Indonesia. Laporan Keuangan dan Publikasi Bank (http://www.bi.go.id).

Kasmir. 2010. Manajemen Perbankan. Jakarta: Raja Grafindo Persada

Laporan Keuangan Bank, www.bi.go.id. "Laporan Keuangan Publikasi Bank".

Lukman, Dendawijaya. 2005. Manajemen Perbankan Edisi Kedua. Jakarta: Ghalia Indonesia

Management. Jakarta: PT Raja Grafindo Persada.

Martono. 2007. Bank dan Lembaga Lain. Cetakan Pertama. Jogyakarta: Penerbit Ekonosia.

Martono. 2010. Bank dan Lembaga Keuangan. Jakarta: Penerbit Ekonosia Kampus Fakultas Ekonomis UII.

Mertika Kirana Rimadhani (2010) dengan topik mengenai "Pengaruh LDR, IPR, BOPO, NPL, APB, AU Dan PDN terhadap ROA pada Bank Pemerintah Daerah periode triwulanan mulai tahun 2006 sampai dengan 2009.

Peraturan Bank Indonesia Nomor 12/10/PBI/ Tahun 2010 Tentang SitemPenilaian Tingkat Kesehatan Bank Umum

Peraturan Bank Indonesia Nomor 6/23/DPNP/ Tahun 2004. Tentang Sitem Penilaian Tingkat Kesehatan Bank Umum

Ruslan, Rosady. 2010. Manajemen Perbankan, Jakarta.

Surat Edaran Bank Indonesia No.7/10/dpnp tanggal 31 maret 2005 Tentang Pengelolaan Kredit Bermasalah. 
Surat Edaran Bank Indonesia Nomor 7 /10/DPNP Tanggal 31 Mei 2005. Tentang Laporan Harian Bank Umum.

Surat Edaran Bank Indonesia No. 23/17/BPPP/ Tanggal 28 februari 1992. Tentang Perhitungan Kewajiban Penyediaan Modal Minimum

Surat Edaran Bank Indonesia No.6/23/DPNP tanggal 31 Mei 2004.

Surat Edaran Bank Indonesia No.6/23/DPNP/2004 tanggal 31 Mei 2004, Tentang Pedoman Perhitungan Rasio Perbankan (http://www.bi.go.id).

Surat Edaran Bank Indonesia No.7/10/DPNP/2005 tanggal 31 Maret 2005, Tentang Pedoman Perhitungan Rasio Keuangan (http://www.bi.go.id).

Undang-Undang Nomor 10 Tahun 1998 Tentang Perbankan.

Veithzal Rivai, Andriana Permata dan Ferry N Idroes. 2007. Bank and Financial Institution

Veithzal Rivai. 2007. Bank and Financial Institution Management. Jakarta: PT. Raja Grafindo Persada.

Winda Ayu Wijayanti (2011) dengan topik mengenai "pengaruh LDR, APB, NPL, FACR, PR, IRR, PDN dan BOPO terhadap ROA pada Bank swasta nasional go public 2006 sampai dengan 2009”. Skripsi sarjana terbitan 